\title{
THE DEVELOPMENT OF THE GUARANTEE AGAINST SELF-INCRIMINATION IN THE BRAZILIAN CONSTITUTIONAL SYSTEM: DIFFERENT VIEWS ON A COMMON LEGAL AND POLITICAL INSTITUTE
}

\begin{abstract}
The right to silence, and the broader guarantee against self-incrimination, is a juridical construction that found in Latin America a fertile ground for its development. Considering the common history of authoritarian dictatorships and the subsequent resistance to oppression-based legal culture, most Latin American constitutions provided clauses that protected the criminal defendant against physical or psychic abuse and violent means of proof from the State. Therefore, constructing a dialogue between the jurisprudence of Latin American Constitutional Courts, as well as the Inter-American Court of Human Rights, is utterly important as a means to build a minimal standard of efficacy.
\end{abstract}

\section{Keywords}

guarantee against self-incrimination - right to silence - Latin America - Inter-American Court of Human Rights

* Professor at Seune Law School (AL). LLM Candidate, Federal University of Alagoas, Brazil (UFAL); Specialist in Criminal Sciences (UNIDERP) and International Criminal Law (Siracusa International Institute for Criminal Justice and Human Rights). Judge's Assistant at Pernambuco Court of Justice, Brazil (TJPE). Email: rodrigues.paulogustavo@gmail.com. 


\section{INTRODUCTION}

The right to silence or guarantee against self-incrimination, as further explained and differentiated below, is not a novelty in modern law nor is it a recent construction of Western juridical culture. As Perez Luño wrote, though the consolidation of fundamental rights as constitutional norms is a relatively new phenomenon, its roots go back and are intimately linked to the historical vicissitudes of human reasoning. ${ }^{1}$

The first mentions to the right to silence and self-incrimination are from the fifth century AD. The historical references go back to commentary of Saint John Chrysostom on Saint Paul's Letter to the Hebrews, where he said that only before God the revelation of one's guilt is indispensable, therefore a man cannot be obliged to acknowledge his sins before men. ${ }^{2}$

During the following centuries, in the process of evolution and design of fundamental rights, the right to silence would acquire new features, going from a simple prohibition of coercive methods to obtain a confession, to a guarantee against any collaborative posture of the accused with the production of evidence, then becoming a generic right against self-incrimination.

This article intends to discuss briefly the recent constitutional history of Latin America, as a means to understand the role played by the guarantee against self-incrimination in the consolidation of his history. The article will attempt a dialogue between the comprehension of the guarantee in Brazilian juridical culture, the jurisprudence of the InterAmerican Court of Human Rights (IACHR) and other Constitutional Courts of Latin America, identifying some similarities and differences within each Court's dealing with this particular legal right as a way to build a minimal standard of human rights protection, as the right interacts with other constitutional realities.

1 A. E. P. Luño, Los Derechos Fundamentais (Fundamental Rights), Madrid: Tecnos 1995, p. 30.

${ }^{2}$ M. S. Albuquerque, A Garantia de não auto-incriminação: extensão e limites (Guarantee against self-incrimination: extension and limits), Belo Horizonte: Del Rey 2008, p. 26. 


\section{THE GUARANTEE AGAINST SELF-INCRIMINATION AS A POLITICAL NECESSITY IN LATIN AMERICA}

It is interesting to notice that the guarantee against self-incrimination, though historically recognized, is not expressly contained in all postwar human rights documents. The Universal Declaration of Human Rights and the European Convention of Human Rights, for example, have no such provision, though it may be legally constructed from both by an expansive interpretation of the presumption of innocence and due process of law. Only in the 1960s did it begin to appear, first in the International Covenant on Civil and Political Rights (ICCPR) and the American Convention of Human Rights (ACHR).

Not only did the ACHR have a provision against self-incrimination as a minimal guarantee, but also a clause invalidating any coerced confession. It is thus relevant to investigate which particular reasons made this provision so necessary. Aside from the history of violent colonization, European exploitation and disturbed independence processes that left a legacy of oppression resistance, it is notorious that, during the 1960s, 70s and 80s, many coup d'états took place in Latin American countries, instituting authoritarian and dictatorial regimes. This created an antidemocratic aura that desolated the entire region and favoured a state of constant and institutionalized violations of human rights. The historical reports from this period show the most basic violations of rights and freedom, with many cases of summary executions, forced disappearances, torture, ideological persecution, arbitrary arrests and abolition of the rights to speech, reunion and association. ${ }^{3}$

Only at the end of the century began the internal processes of democratization and, with them, the spread of internationally accepted human rights in the constitutional realities of this region. It is interesting

${ }^{3}$ F. Piovesan, Sistema interamericano de proteção dos Direitos Humanos: impacto, desafios e perspectivas à luz da experiência latino-americana (Interamerican System of Human Rights Protection: Impact, Challenges and Perspectives in light of the Latin American Experience), [in:] A. V. Bogdandy, F. Piovesan, M. M. Antoniazzi (eds.), Direitos Humanos, Democracia e Integração Jurídica na América do Sul (Human Rights, Democracy and Juridical Integration in South America), Rio de Janeiro: Lumen Juris 2010, p. 336. 
to note, as did Luño, that in its objective axiological meaning, fundamental rights represent the result of a basic accord between different social powers, obtained from the tensional relations and from the cooperative efforts towards common goals. ${ }^{4}$

As the revolutionary momentum of the eighteenth century indicated a rejection of ideals linked to the ancient régime, allowing the development of the fundamental rights and freedoms of the present day, the same occurred in Latin America in its democratization period, orienting its normative constructions in view of eliminating all authoritarian residues of its dictatorships, at least at the constitutional level.

In this context, we invoke the words of Flavia Piovesan, when she identified the major challenges of Latin America, as making a 'definitive rupture with the legacy of dictatorial authoritarian culture and consolidate[ing] a democratic regime, with plain respect for human rights, broadly considered'. ${ }^{5}$ The American Convention of Human Rights, for instance, though originally signed in 1969, was only ratified by Argentina in 1984, Brazil in 1992, Chile in 1990, Peru in 1978 and Paraguay in 1989, when democratic regimes - or close to, at least - had already been implanted. ${ }^{6}$

That said, the common past and similitudes of political movements and moments of Latin American countries allowed the development of very similar constitutions in terms of their regard for fundamental rights and freedoms of the public, especially because they always reflected a resistance point against authoritarian practices. Gonzalo Aguilar Cavallo observes that, in the last three decades, a common body of principles and rules was shared by Latin American states, coming from its political, social and institutional evolution and from the interaction between internal judicial institutions and a dialogue with the Inter-American system of human rights. ${ }^{7}$

${ }^{4}$ See Luño, supra note 1, p. $20-21$.

${ }^{5}$ See Piovesan, supra note 3, p. 336.

${ }^{6}$ Information available at: https://www.cidh.oas.org/basicos/portugues/d. Convencao_Americana_Ratif..htm [last accessed 20.10.2017].

7 G. A. Cavallo, Emergencia y Consolidación de un Derecho Americano de los Derechos Humanos (Emergence and Consolidation of an American Law of Human Rights), [in:] A. V. Bogdandy, F. Piovesan, M. M. Antoniazzi (eds.), Direitos Humanos, Democracia 
The right to silence and against self-incrimination, then, was introduced in the American Convention of Human Rights as a protective tool for the citizen against physical and moral violence from the State, specifically related to the history of tortured confessions and violent means of questioning and producing evidence, in its criminal procedure facet.

Historically linked to the combat against absolutist regimes and Inquisition-like methods of criminal prosecution, the right to silence found a receptive soil for its strengthening in the Latin American democratization period, becoming indispensable since it fulfilled a political need to reaffirm individual liberties. Thus, Brazil, Chile, Argentina, Paraguay, Colombia and so many others introduced clauses that, in a larger or more restricted manner, established one's right not to be forced to testify against oneself.

\section{DELIMITING THE RIGHT TO SILENCE AND AGAINST SELF-INCRIMINATION IN BRAZILIAN LAW}

As already said above, the right to silence is no novelty, having been developed and strengthened both in civil law countries, as the nemo tenetur se detegere clause or nemo se ipsum accusare tenetur (as commonly refered to in European), and common law countries, as the privilege against self-incrimination.

Though it was originally created because of the political need to protect against the abuses perpetrated by absolutist regimes in criminal procedures, ${ }^{8}$ as a mere protection of physical and psychic integrity of the accused against torture and cruel methods of interrogation, the evolution of the means of proof and investigation techniques forced the construction of a new efficacy field.

Brazilian jurisprudence and doctrine then began to discuss the application of the right against self-incrimination not against means of proof that demand active cooperation of the accused (interrogation,

e Integração Jurídica na América do Sul (Human Rights, Democracy and Juridical Integration in South America), Rio de Janeiro: Lumen Juris 2010, p. 399.

${ }^{8}$ See Albuquerque, supra note 2, p. 28. 
participation in line-ups, fact reconstitution, giving biological or other personal material for comparative tests, breathalyzers, etc.), but also for those that demand a passive posture (non-invasive gathering of DNA, body searches, personal inspection, etc.)

This extension would come from the axiological nature of nemo tenetur se detegere, intrinsically related to due process, presumption of innocence, right to a defence and human dignity. ${ }^{9}$ It is said that although Brazilian Constitution was not sufficiently eloquent, as it states only the right to remain silent, the guarantee against self-incrimination, in all its amplitude, is extracted from all these other fundamental rights.

From the presumption of innocence is built the rules of probatory burden, since the establishment of a legal status previous to the criminal conviction fixes the responsibility on the State, not the citizen, to construct a case that allows a judge or a jury to form a conclusion about criminal responsibility. According to Brazilian current criminal procedure doctrine, the accused cannot be coercively led to produce evidence that could serve his conviction, as this is the constitutional burden of the State.

Furthermore, instrumentalizing the individual, turning him or her into an object of proof and suppressing their will as a way of coercing him into a posture that will lead, at the end, to their imprisonment, is conduct that would undoubtedly go against human dignity. In Kant's perspective, for instance, a human is an end in himself, not as a means serving a harmful state purpose. ${ }^{10}$

The excessive extension of the efficacy field for the guarantee against self-incrimination, performed by some sectors of Brazilian doctrine and jurisprudence, has received several critiques. Schirmer Albuquerque comes to the point of saying it creates a kind of corporal immunity with no rational grounds ${ }^{11}$, which, according to our view, endangers the

${ }_{9}$ M. E. Queijo, O direito de não produzir prova contra si mesmo (The right to not produce evidence against yourself), São Paulo: Saraiva 2012, p. 93-102.

10 '[F]or a human being can never be manipulated merely as a means to the purposes of someone else and can never be confused with the objects of the Law of things [Sachenrecht]. His innate personality [that is, his right as a person] protects him against such treatment' - I. Kant, The Penal Law and the Law of Pardon [in:] M. Tonry (ed.), Why Punish? How Much? A reader on Punishment, New York: Oxford University Press 2011, p. 32.

${ }^{11}$ See Albuquerque, supra note 2, p. 33. 
gathering of sufficient evidences to allow the judge or jury to develop a contextualized conviction regarding the charges. ${ }^{12}$

Adopting the terminological distinctions developed by Ingo Sarlet, ${ }^{13}$ it is understood that the prohibition against self-incrimination is a fundamental right-guarantee, since - in its essence - it is a rule to instrumentalize state actions towards the protection of fundamental rights, as individual freedom, physical integrity, autonomy of will and human dignity, but it also has a subjective element that supports individual juridical positions.

The comprehension of the self-incrimination, mainly, as a guarantee that finds in the right to silence a means of expression, allows the conclusion that Albuquerque reached when he related self-incrimination with a correlated fundamental right. He stated that the refusal to contribute to the production of evidence is justifiable when said contribution hurts, in any way, the fundamental rights of the one refusing, and not merely for the fear of being convicted, ${ }^{14}$ since there is no fundamental right to escape criminal responsibility.

Aside from obvious illegal conduct (torture, for instance), linked to the genesis of the right to silence, it is noticeable that other probatory mechanisms can also effectively violate the guarantee against selfincrimination when they violate physical integrity (corporally invasive means of proof) or the autonomy of will and human dignity.

Extending the right against self-incrimination to oral evidence, Brazil's Federal Supreme Court has already declared the impossibility of using confessions that happened during witness testimonies in which

12 P. G. Rodrigues, A convicção contextualizada e a verdade negociada no processo penal: desmistificando a confissão como elemento de convencimento pleno do julgador penal (The contextualized conviction and the negotiated truth in the criminal process: demystifying confession as an element of full conviction of the criminal judge), „Revista Brasileira de Direito Processual Penal" vol. 3, n. 1, p. 103-130. Available at: https:/ / doi.org/10.22197/rbdpp.v3i1.32. [last accessed 23.10.2017]

13 I. W. Sarlet, A eficácia dos direitos fundamentais. Uma teoria geral dos direitos fundamentais na perspectiva constitucional (The efficacy of fundamental rights. A general theory of fundamental rights in a constitutional perspective), Porto Alegre: Livraria do Advogado 2012.

${ }^{14}$ See Albuquerque, supra note 2, p. 49-50. 
the person is not fully alerted of his/her right against self-incrimination, ${ }^{15}$ as well as extended the efficacy of the right to silence to testimonies given during Parliament Inquiry Commissions. ${ }^{16}$ Furthermore, it has also decided that the voluntary absence of the defendant during the hearings or trials is an expression of his right to silence. ${ }^{17}$

Regarding to material proofs, there has been a notorious ruling declaring unconstitutional the obligation to submit to breathalyzers, ${ }^{18}$ and Brazil's Superior Court of Justice reasoning that forcing the defendant to confront other defendants or witness is a violation of his or her right against self-incrimination. ${ }^{19}$

Brazilian doctrine and jurisprudence have always led the way in recognizing that the extension of the guarantee against self-incrimination for more than the mere right to silence contained in its Constitution, being a logical consequence of other fundamental rights involved or because of the American Convention of Human Rights (Pact of São José da Costa Rica).

In this perspective, although there is a noticeable increase in critiques to this posture, the guarantee against self-incrimination is often seen as a (practically) full immunity of the accused regarding participation in probative activity, regardless if the evidence demands an active or passive collaboration, bodily invasion or not. There is no custom of using hermeneutical techniques such as proportionality to amplify the sphere of collaboration of the accused with the production of criminal evidence, from the perspective of necessity to pursue an effective prosecution of criminal activities.

Being that the guarantee against self-incrimination is a historical and supra-state construction, it is essential that knowledge and dialogue with other constitutional experiences is used to verify the sphere of protection recognized for this institution in other countries, to create a minimal standard of its efficacy.

15 Superior Tribunal de Justica do Brasil, Acórdão no RHC 122.279. Judgment of 12.08.2014.

16 Supremo Tribunal Federal do Brasil, Acórdão no HC 119.941. Judgment of 25.03.2014.

17 Supremo Tribunal Federal do Brasil, Acórdão no HC 109.978. Judgment of 18.06.2013.

18 Supremo Tribunal Federal do Brasil, Acórdão no HC 93.916. Judgment of 10.06.2008.

${ }_{19}$ Superior Tribunal de Justica do Brasil, Acórdão no RHC 60.725/SP. Judgment of 15.09.2015. 


\section{THE JURISPRUDENCE OF THE INTER-AMERICAN COURT OF HUMAN RIGHTS (IACHR)}

The Inter-American Court of Human Rights (IACHR) has had little to say about the theme, and, when it has, it was not treated as a matter of probative law, but in regard to the preservation of individual liberties, which, as will be seen, is the essence and genesis of the right against self-incrimination.

Cantoral Benavides v. Peru was a case in which a citizen from Peru was convicted of treason from an investigation where he spent several days illegally detained and being physically and mentally tortured. The IACHR concluded that the plaintiff was coerced into self-incrimination, his confession being essential to his conviction. ${ }^{20}$ Furthermore, it was declared that imprisonment for longer than legally determined, and interrogation in unusual times and places, constitute ways of coercion.

Following the same path, in the paradigmatical case of torture repression Tibi v. Ecuador, the accused was tortured by police authorities with the objective of making him confess to the crime of drug trafficking. The IACHR concluded that he was subjected to these acts with the purpose of breaking his psychic resistance and forcing him to self-incriminate, ${ }^{21}$ which violated Article 8.2.g of the American Convention of Human Rights.

We can always see the right against self-incrimination being referenced by the IACHR as a protection of the citizen's personal integrity against state abuse, coercion and torture, such as in the case Maritza Urrutia v. Guatemala. This case stands, for the Court, as a point of control for the residue of dictatorial authoritarian culture in Latin America. In Cabrera Garcia y Montiel Flores v. Mexico, the IACHR decided that the confession is invalid even if not obtained by direct torture but in the days following while the accused was still under feelings of fear and angst. ${ }^{22}$

${ }^{20}$ IACHR, Cantoral Benavides v. Peru, Judgment of 18.08.2000, available at http:/ / www.corteidh.or.cr/docs/casos/articulos/Seriec_69_esp.pdf [last accessed 07.11.2016].

${ }^{21}$ IACHR, Tibi v. Ecuador, Judgment of 07.09.2004, available at http:/ / www.corteidh. or.cr/docs/casos/articulos/Seriec_114_esp.pdf. [last accessed 16.05.2017].

${ }_{22}$ M. G. Juárez, La regla de exclusión de la prueba prohibida en la jurisprudencia internacional sobre derechos humanos: el caso de la tortura y el juicio de ponderación, (The Rule of Exclusion of Forbidden Evidence in International Jurisprudence of Human Rights: The Case of Torture and 
The Palamara Iribarne v. Chile case brings an interesting peculiarity, since it interprets the Military Justice Code of Chile, which did not contemplate a guarantee against self-incrimination for those prosecuted, according to its rulings. Therefore, the accused would not be alerted to the right to remain silent, since he did not have this right. It was said, by the State, that the reason it did not violate the American Convention was that the accused was not being forced to tell the truth, because he would not have to take the oath to tell the truth. ${ }^{23}$ This argument was dismissed by the Court, which recognized a violation of human rights by the simple fact the he was not alerted of his Convention-derived right to silence and the potential incriminating uses of his words.

The relevance of the case is the demonstration of the position of the Court regarding the direct normative strength of the human rights listed in the American Convention, regardless of their specific introduction in internal positive law. This conclusion contributes to the Brazilian reality in the way that its constitutional norms are more restrictive than that of the Convention. That said, the Court's understanding blocks the arguments of those who invoke Brazilian's Constitution to sustain a restrictive approach to the guarantee.

It is clear that the IACHR still looks at the guarantee against selfincrimination in its most embryonic phase, protecting the personal integrity of those accused of a crime against state abuse in collecting their testimonies, without a concern for analysing other means of proof. Even if the evolution of investigative activity is recent and there has not been many cases before the Court, Mariano Juarés points to cases that justify some mention regarding the validity of various means of obtaining evidence, which the Court silenced. ${ }^{24}$

In this sense, although there are meaningful contributions in the jurisprudence of IACHR, it is noticeable that the search for a minimal standard of protection of the guarantee against self-incrimination in Latin

Ponderation), „,Anuario De Derecho Constitucional Latinoamericano", available at http:/ / www.corteidh.or.cr/tablas/r29680.pdf. [last accessed 27.11.2016].

${ }^{23}$ IACHR, Palamare Iribarne v. Chile, Judgment of 22.11.2005, available at http:/ / www.corteidh.or.cr/docs/casos/articulos/Seriec_135_esp.pdf. [last accessed 04.04.2017].

${ }^{24}$ See Juárez, supra note 22. 
American must pass through a study of the theme from the perspective of the Constitutional Courts of the region.

\section{THE GUARANTEE AGAINST SELF-INCRIMINATION IN THE JURISPRUDENCE OF LATIN AMERICAN Constitutional COURTS}

One cannot deny the importance of comparative study as an interpretation tool, being extremely relevant to look over other constitutional experiences to form a new global juridical culture. Looking through a constitutional trend of internationalization of human rights, the search for the interpretation that other jurisdictions give to some common institutions leads to an expansion and standardization of certain guarantees.

However, a comparative study cannot be limited to just the citation of foreign legislations, which is basically equivalent to the rhetorical technique of an argument from authority. Cardoso identifies comparative study as a research towards a better model, conducted by an analysis of timely materials taken from the foreign models, assessing their similarities and differences. ${ }^{25}$ In this context, the comparative study must be accompanied by not only another country's legislation, but mainly the solution that its jurisprudence finds for similar situations, allowing a dialectic from the social, economic and cultural reality in which that norm is inserted. ${ }^{26}$

Thus, it is proposed here to investigate the constitutional experience of the right against self-incrimination in recent Latin American cases, especially from Constitutional Courts with regional expression, such as Argentina, Chile, Colombia, Peru and Brazil.

The option for Latin America constitutes a methodological option similar to that of Aguilar Cavallo in his construction of an idea of American Law of Human Rights, ${ }^{27}$ derived from the observation that Latin countries have historical, social and cultural roots distinct from

${ }^{25}$ G. V. Cardoso, O Direito Comparado na Jurisdição Constitucional (Comparative Law in Constitutional Jurisdictions), "Revista Direito GV" Jul.-Dec./2010, Issue 6 (2), p. 471.

${ }^{26}$ Ibid. at p. 472.

${ }^{27}$ See Cavallo, supra note 7, p. 399-400. 
those with Anglo-Saxon backgrounds, sharing with each other a view on human rights built on very similar grounds.

\subsection{ARgentina}

The current Argentine Constitution provides a right against selfincrimination in Article 18, which, among other things, states that "nadie puede ser obligado a declarar contra sí mismo" 28 (no one can be obliged to declare against himself).

The Corte Suprema de Justicia de La Nacion Argentina has dealt with the subject a few times, a noticeable case that of Cesar Alejandro Baldivieso, who submitted to a urgent medical procedure, being at the risk of death, to remove a certain amount of drugs in his digestive system for transportation and ending up being convicted solely with the evidence extracted from his body ${ }^{29}$.

Though some Judges voted for the invalidation of the evidence for violation of medical-patient privilege, it was decided that the reason would be the right against self-incrimination, as a corollary of the right to human dignity. The Court said that the State is not allowed to investigate crimes by using immoral means, as is the act of take advantage of an imminent risk of death. ${ }^{30}$ It was said that making the accused have to choose between producing evidence of his crime and death submitted him to a cruel and undignified choice, equivalent to coercion.

With this decision, the Argentine Supreme Court followed the trend already analysed above of expanding the right against self-incrimination beyond mere silence, entering the probative sphere and rejecting, on some level, coercion to active or passive-invasive participation of the accused on the production of evidence.

${ }^{28}$ Available at http:/ / servicios.infoleg.gob.ar/infolegInternet/anexos/0-4999/804/ norma.htm [last accessed 20.10.2017].

${ }^{29}$ Corte Suprema de Justicia de la Nacion Argentina, Recurso de Hecho n. 4733, available at http:/ / sjconsulta.csjn.gov.ar/sjconsulta/documentos/getDocumentosExterno. html?idAnalisis=683039 [last acessed 15.11.2016].

${ }^{30}$ Ibid. at p. 3. 
Actually, Argentine jurisprudence, beyond the Supreme Court, argues substantially about this theme from a probative perspective. Another relevant case was the Alvarez case $^{31}$, in which it was said that the accused was detained under the suspicion of carrying drugs within his digestive tract. A medicine was provided to him to stimulate the natural evacuation process, without him being alerted of the incriminatory nature of the evidence he was expelling. An Argentine Court decided, however, that there had been no violation of the right against self-incrimination, since there was no coercive method that went against his will, since the evacuation would happen naturally and the procedure was only to hasten it.

Other discussions have occurred in Argentine criminal doctrine, especially regarding a provision of the criminal procedure code that allows the coerced extraction of genetic material for DNA testing. It has been found that the solution adopted by Argentinian jurisprudence always passes through a proportionality review as well as its subprinciples. ${ }^{32}$ With this understanding, coercive probative measures with participation of the accused are usually allowed, since they do not cause him any harm or damage to his integrity ${ }^{33}$, as, for instance, DNA testing with hair or saliva, and other measures followed by medical guidance and judicial approval.

This way, Argentina does not make the guarantee against selfincrimination an absolute standard of immunity, as do some of the Brazilian criminalists, and always searches for reasonability or proportionality as a hermeneutical element to allow, in certain ways, the forced participation of the accused, in many passive and non-invasive cases, thus mitigating his autonomy of will, but always sustaining his health and integrity as a minimal standard of protection.

31 See Queijo, supra note 9, p. 344.

${ }^{32}$ E. P. Assis, Do conflito entre o direito à produção de provas e o direito a não autoincriminação - nemo tenetur se detegere - no tocante às intervenções corporais (The Conflict between the Right to Produce Evidence and the Right Against Self-Incrimination), Rio de Janeiro: Lumen Juris 2016, p. 139.

33 Ibid. at p. 133. 


\subsection{Peru}

Peru does not have a specific constitutional provision regarding this right, although infra-constitutional legislation brings some protections related to the right to silence in interrogations. The leading case of the guarantee against self-incrimination, referenced in subsequent rulings by the Constitutional Court, is the Demanda de Inconstitucionalidad $\mathrm{n}$. $003 / 2005^{34}$, in which were established the origins, normative sources and delimitations for its application in Peruvian law.

The Court discussed, in this case, the alleged unconstitutionality of a law that established effective collaboration (a sort of plea bargain) as a probative instrument in organized crime investigations. It was alleged that the provision of rewards and prizes was an immoral stimulation to the production of self-incriminating evidence and, therefore, a violation of the conventional guarantee.

After constructing the right against self-incrimination from other constitutional rights, and, especially, the American Convention of Human Rights, the Court ruled that the essence of this guarantee is the autonomy of will, in a way that according to the Court, should be interpreted in a broad aspect, reaching all information obtained from the accused without his will. ${ }^{35}$ Therefore, the Court ruled that this awarded collaboration did not violate the guarantee against self-incrimination, due to the fact that its sphere of protection is not incompatible with the accused's freedom to voluntarily testify, in the interest of receiving processual benefits.

In a more recent case, the Constitutional Court analysed a specific situation where the Judge stated that the defendant's silence would be taken into consideration in his ruling, which compelled the accused to answer the questions even though he had initially opted for remaining silent. ${ }^{36}$ Looking at this scenario, the Court made it clear their disapproval

${ }^{34}$ Tribunal Constitutional de Peru, Demanda de Inconstitucionalidad n. 003.2005, Judgment of 09.08.2006, available at http:/ / www.tc.gob.pe/jurisprudencia/2006/000032005-AI.html [last acessed 02.12.2016].

${ }^{35}$ Ibidem.

36 Tribunal Constitutional de Peru, Recurso de Agravio Constitucional n. 03021.2013, Judgment of 20.06.2014, available at http:/ / www.tc.gob.pe/jurisprudencia/2014/030212013-HC.pdf [last accessed 05.04.2017]. 
about the posture of judges that induce the defendant into error to obtain information, as well as to the lawyers that do not orient their clients in the best ways to exercise their constitutional rights.

However, the conviction was not overturned due to the fact that the Judge did not use the self-incriminatory testimony in his reasoning, grounding itself on other evidence, subjecting the right against selfincrimination to a ponderation based on the pas de nulité sans grief rule.

The discussion about self-incrimination in Peru is still in its infancy when compared to those of other countries, especially since there is not a constitutional provision supporting it. In trials in which it has been recognized, it is seen in a protective feature regarding interrogation, protecting mainly the accused's autonomy of will.

\subsection{COLOMBiA}

The Colombian Constitution of 1991 provides in Article 33, the provision that '[n]adie podrá ser obligado a declarar contra sí mismo o contra su cónyuge, compañero permanente o parientes dentro del cuarto grado de consaguinidad, segundo de afinidad o primero civil $^{\prime 37}$ (no one can be obliged to declare against oneself or against one's spouse, permanent companion or relatives inside a fourth degree of consanguinity, second of affinity or first civil), expanding the immunity to incrimination against close relatives.

The Colombian Constitutional Court has faced the matter of self-incrimination multiple times. In a one ruling, they decided the constitutionality of a disposition of the Criminal Procedure Code that established, as a condition to a provisory release pending trial, that the accused would cooperate with the ascertainment of facts. ${ }^{38}$ Understanding that this device violated the presumption of innocence, deformed the probative burden of the prosecution and could coerce the accused to

37 Available at: http://www.corteconstitucional.gov.co/inicio/Constitucion $\% 20$ politica\%20de\%20Colombia\%20-\%202015.pdf [last accessed 20.10.2017].

${ }^{38}$ Corte Constitutional da Republica de Colombia, Acórdão C-776/01, Judgment of 25.07.2001, available at http:/ / www.corteconstitucional.gov.co/relatoria/2001/C-776-01. htm. [last accessed 15.11.2016]. 
produce self-incriminatory evidence (over the risk of his freedom being revoked), the Court found this provision unconstitutional. ${ }^{39}$

It seems as if Colombian jurisprudence deals with self-incrimination in regards to the presumption of innocence and probative burden, rejecting requiring the active participation of the accused and his collaboration with the state's duty to prove criminal responsibility. However, the Colombian Constitutional Court does not interpret this circumstance as a broad permission for the accused to abuse his right to a defence or due process, or to obstruct the investigation.

A more recent case sheds a light into this, where the Court decided the constitutionality of a law regarding the disciplinary regime of the National Police, which gave a larger sentence to those who did not take responsibility for their actions. The Court, however, gave it a conditional practicability, ruling that it would be unconstitutional to increase a sentence in facing the silence of the defendant. However, it was recognized as constitutional an increase of sentences of those who behave intentionally to obstruct or mislead the investigation ${ }^{40}$.

This is a similar position to the one that Brazilian Supreme Court adopted in case RE 640.139/DF, ${ }^{41}$ in which they decided that the conduct of using a fake identity when arrested to hide a criminal background was not protected by the right to defend oneself, since it is a malicious act that violates due process and the administration of justice, in such a way that must be criminalized.

Actually, the Colombian Court, in more than one case, highlighted that the guarantee against self-incrimination does not cover conduct that is against procedural good faith. They decided, in Sentencia C-228/ 2003, that an article of the Military Penal Code that gave an increased sentence to the defendant that accused a third party of his crime was constitutional, since it was conduct in bad faith that was not protected by any constitutional guarantees. ${ }^{42}$

${ }^{39}$ Ibidem.

${ }^{40}$ Corte Constitutional da Republica de Colombia, Acórdão C-258/11, Judgment of 06.04.2011, available at http:/ / www.corteconstitucional.gov.co/relatoria/2011/C-258-11. htm. [last accessed 15.11.2016].

${ }^{41}$ Brasilian Federal Supreme Court, Acórdão no RE 640.129-RG/DF, Judgment of 14.10.2011.

${ }^{42}$ Corte Constitutional da Republica de Colombia, Acórdão C-228/03, Judgment of 
Regarding state conduct of an invasive nature, the leading case in Colombian jurisprudence is Sentencia C-822/2005, in which the Constitutional Court decided the constitutionality of certain articles of the Criminal Procedure Code that provided a coercive realization of invasive means of proof.

It was understood that, in the cases that the accused did not consent to bodily intervention, the matter would be brought to a judge and, should he understand it to be necessary, under a proportionality test, the intervention could be performed coercively, ${ }^{43}$ as long as certain restrictions regarding human dignity, health and physical integrity were maintained.

\subsection{CHILE}

Chile does have a constitutional right to not declare against oneself, being the broad guarantee against self-incrimination built, in the same way, from dispositions regarding presumption of innocence, right to a defence and personal freedom, besides the international treaties ratified by the country. ${ }^{44}$

One case in Chile's constitutional jurisprudence worth highlighting, given its similarity to a current controversy in Brazil, involved the forced administration of a breathalyzer to detect drunk driving. Chilean internal legislation states that the refusal to take an alcohol detection test ${ }^{45}$ was a transit infraction.

18.03.2003. Available at http:/ / www.corteconstitucional.gov.co/relatoria/2003/C-228-03. $\mathrm{htm}$. [last acessed 17.11.2016].

${ }^{43}$ See Assis, supra note 32, p. 158.

${ }^{44}$ M. F. Z. Garcia, El cinturon de seguridad del derecho a guardar silencio/prestar declaracion del detenido: la intervencion oportuna y efectiva del defensor (The Bell of Security of the Right to Remain Silent/Admit Statements of the Detained: The Effective Intervention of the Lawyer), "REJ - Revista de Estudios de la Justicia" 2005, Issue nr 6, available at http:/ / www.rej. uchile.cl/index.php/RECEJ/article/viewFile/15076/15494 [last accessed 15.11.2016].

45 Article 195 of Traffic Law (Ley de Tránsito) is written as follows, freely translated: "the unjustifiable refusal of a driver to submit to breathing means of proof or other scientific exams to determine the presence of alcohol or psychotropic substances in his body, as established in article 182, is sanctioned with a fine of three to ten monthly tax measures and with the suspension of his driving license for a month". 
On a judgment issued on 20 October 2016, the Chilean Constitutional Court decided that this infraction did not violate the right against selfincrimination, since it had a uncertain result. ${ }^{46}$ They indicated that constitutional jurisprudence demanded that such a right must involve a matter of a criminal nature, and that any such declaration would have to be taken under oath, which was not the case.

It is, indeed, a very restricted interpretation, but it is compatible with the country's judicial culture, since their legislation has several devices that allow coerced means of proof, requiring only a judicial warrant in cases of resistance,${ }^{47}$ but always preserving the physical integrity of the accused.

\section{CONCLUSIONS}

The right against self-incrimination is an achievement of the highest importance. In the Latin American constitutional context, it has been consolidated as an important instrument of resistance against abusive and violent methods of evidence production, which ravaged this region during periods of governance by dictatorial military regimes.

Although Brazilian juridical culture has always walked a path of hypervaluation of this guarantee, constructing an almost full immunity of the accused against all sorts of collaboration with the state during evidence production, other Latin American countries are not so strict. They use elements of proportionality to evaluate the facts on a caseby-case standard, determining the legitimacy of such measures using a proportionality test of the degree of affection of one's autonomy of will and the importance of that evidence.

This analysis is important due to the fact that these countries have investigated and developed this scope of this guarantee under the similar historical and cultural perspectives, and under the influence of the same regional system of human rights protection. In this way, a dialogue with Latin American constitutional realities favours the construction

46 Tribunal Constitutional do Chile, Rol 2936-15, Judgment of 20.10.2016, available at http:/ / www.tribunalconstitucional.cl/wp/ver.php?id=3344 [last accessed 15.11.2016].

47 See Assis, supra note 32, p. 160-167. 
of a minimal standard of protection of the guarantee against selfincrimination, predicated on the American Convention of Human Rights.

Under this perspective, it is noticeable that Latin American Constitutional Courts find a ground floor of this right to be protecting physical and psychic integrity of the accused against state abuse on coerced practices of evidence gathering. There is a certain confluence on using proportionality as a hermeneutical element of tests of these principles, in order to allow a degree of balancing one's autonomy of will in favour of non-invasive coerced means of proof, limited, of course by maintaining the accused's bodily integrity.

Certain countries oblige a detained driver, for example, to perform a breathalyzer test (in which the accused's sole conduct is to blow into the device), authorize the forced collection of genetic material for DNA testing (with hair or saliva, in a non-invasive manner), among other means of proof that demands certain degree of collaboration from the accused. These seem to be essential for a correct probative construction of the criminal process and an effective prosecution, balancing the state's duty to punish a crime with the accused's fundamental rights. 
